\title{
ANÁLISE DOS
}

PROJETOS E DAS OBRAS NO PALÁCIO FOZ, EM LISBOA, ENTRE 1887 E 1904:

CONTRIBUTO PARA A RECONSTITUIÇÃO ARQUITETÓNICA E CONSTRUTIVA DOS ELEMENTOS NA SUA ENVOLVENTE

ANABELA MENDES MOREIRA, INSTITUTO POLITÉCNICO DE TOMAR, TOMAR, PORTUGAL.

Doutora em Engenharia Civil pela Faculdade de Ciências e Tecnologia da Universidade de Coimbra. Mestre em Ciências da Construção. Licenciada em Engenharia Civil. É docente no Instituto Politécnico de Tomar.

ORCID: https://orcid.org/0000-0002-9636-1796

E-mail: anamoreira@ipt.pt

INÊS DOMINGUES SERRANO, INSTITUTO POLITÉCNICO DE TOMAR, TOMAR, PORTUGAL.

Doutora em História da Arquitectura pela Faculdade de Arquitectura da Universidade de Lisboa. Mestre em História e Teoria da Arquitectura. Licenciada em Arquitectura. É docente no Instituto Politécnico de Tomar desde 1998.

ORCID: http://orcid.org/0000-0001-7200-4965

E-mail: inesserrano@ipt.pt

DOI 06/07/2018 APROVADO

http://dx.doi.org/10.11606/issn.1980-4466.v14i27p58-85 $27 / 06 / 2019$ 


\section{ANÁLISE DOS PROJETOS E DAS OBRAS NO PALÁCIO FOZ, EM LISBOA, ENTRE 1887 E 1904: CONTRIBUTO PARA A RECONSTITUIÇÃO ARQUITETÓNICA E CONSTRUTIVA DOS ELEMENTOS NA SUA ENVOLVENTE}

ANABELA MENDES MOREIRA, INÊS DOMINGUES SERRANO

\section{RESUMO}

A caracterização arquitetónica e construtiva de um edifício é fundamental em qualquer processo de intervenção. A proficiência desses processos depende, em grande medida, do conhecimento profundo do edifício e da correta interpretação das alterações que nele se tenham operado. A reconstituição construtiva, sobretudo de edifícios mais antigos e que foram submetidos a maior número de intervenções no decurso do tempo, nem sempre é possível, dada a inexistência ou a insuficiência de registos escritos do seu projeto inicial, ou das suas sucessivas alterações. Existem, porém, exceções que se referem principalmente a edifícios com maior notabilidade, onde é possível revisitar o processo projetual, através de registos coevos, e, no caso de obras mais recentes, identificar e analisar os estratos referentes às várias intervenções, através da análise documental geralmente depositada em arquivos institucionais. Neste artigo procede-se à possível reconstituição arquitetónica e construtiva dos elementos do envelope (cobertura e paredes exteriores) de um dos edifícios mais distintos da cidade de Lisboa, o Palácio Foz, erigido na sequência do terramoto de 1755. O trabalho de pesquisa realizado focou-se na análise dos requerimentos submetidos pelo Marquês da Foz à Câmara Municipal de Lisboa no período compreendido entre 1887 e 1904. Os referidos requerimentos correspondem a pedidos escritos de alterações, ampliações e renovações construtivas solicitados pelo proprietário. Este estudo pretende identificar e datar as principais alterações arquitetónicas e construtivas realizadas no envelope do edifício, relativamente à construção inicial, enquadrando-as com as alterações urbanísticas da zona envolvente. Pretende-se, assim, contribuir para a caracterização da história arquitetónica e construtiva do edifício, explicitando a relação entre as práticas construtivas e o contexto urbano durante aquele período.

\section{PALAVRAS-CHAVE}

Património arquitetónico. Espaço urbano. Arquitetura portuguesa. 


\title{
ANALYSIS OF THE PROJECTS OF PALÁCIO FOZ BUILDING, IN LISBON, BETWEEN 1887 AND 1904: CONTRIBUTION TO ARCHITECTURAL AND CONSTRUCTIVE RECONSTITUTION OF THE BUILDING ENVELOPE \\ ANABELA MENDES MOREIRA, INÊS DOMINGUES SERRANO
}

\begin{abstract}
Architectural and constructive characterizations of a building are fundamental in restoration processes. The proficiency of these processes depends, in a great extent, on the deep knowledge of the building and the correct interpretation of the changes that have been made in it. Constructive reconstitution, especially in older cultural heritage buildings which have undergone several changes over time, is not always possible, given the lack of records. However, there are exceptions, e.g. notable buildings, in which it is possible to rebuild the design process through coeval records. This article presents a likely architectural and constructive reenactment of Palácio Foz, one of the most distinguished buildings in Lisbon, built after the earthquake in 1755 . The research work focuses on the analysis of some written requests submitted by the owner, Marquis of Foz, to the Lisbon City Council, between 1887 and 1904. The requests refer to project designs concerning modifications, extensions, and constructive renovations. The study intends to identify the main architectural and constructive changes in the building envelope, and frame them with the urban changes of the surrounding area. Hence, the study aims to contribute to an architectural and constructive characterization of the building, emphasizing the relation between constructive practices and urban context during that period in Lisbon.
\end{abstract}

KEYWORDS

Architectural heritage. Urban space. Portuguese architecture. 


\section{INTRODUÇÃO'}

Na sequência do terramoto de 1755 que atingiu a cidade de Lisboa, muitos edifícios nobres ficaram reduzidos a ruínas. Numa época de graves dificuldades económicas foram várias as famílias nobilitadas que não os puderam reconstruir, ou que o fizeram mais tarde, sendo uma das exceções o Palácio dos Marqueses de Castelo Melhor (FRANÇA, 2004). O edifício foi construído a partir de uma preexistência, localizada numa zona próxima da propriedade original, referindo-se a designação Palácio de Castelo Melhor aos seus promotores iniciais, os marqueses de Castelo Melhor.

No período em que se manteve na propriedade dos marqueses de Castelo Melhor, o edifício foi sendo intervencionado em diversos momentos, resultando na beneficiação e ampliação de algumas dependências.

No final do século XIX, o edifício transitou, por venda, para o Marquês da Foz, advindo daí o nome pelo qual ainda é atualmente conhecido: Palácio Foz.

No início do século XX, o palácio e as suas dependências foram arrendados a Manuel José da Silva, proprietário do Anuário Comercial, e em 1908 hipotecado ao Crédito Predial. Em 1910, com o início do período político da primeira República (1910-1926), o edifício conhece novo proprietário,

1. Este artigo está escrito conforme a norma do Português Europeu (nota do editor). 
o Conde de Sucena (1850-1925). Após a revolução de 28 de maio de $1926^{2}$, que esteve na origem da instauração do Estado Novo (1933-1974), o palácio foi hipotecado pela Caixa Geral de Depósitos, banco estatal, em 1929. Concluído o processo para a sua aquisição ${ }^{3}$ em 1939, foi um ano depois vendido à Fazenda (ATAÍDE, 2010).

Entre 1941 e 1949, decorreram as obras de restauro e ampliação do palácio pelo arquiteto Luís Benavente (1902-1993). Foi a primeira intervenção no edifício com o objetivo expresso da recuperação, adaptação e ampliação dos seus espaços para a instalação de serviços estatais: o Secretariado de Propaganda Nacional (SPN) no corpo principal, e os Serviços de Inspeção Geral dos Espetáculos e de Censura, num edifício novo construído para o efeito. A intervenção envolveu trabalhos de demolição, restauro e construção nova, desenhada numa linguagem mimética ao edifício existente (FERNANDES, 1999).

Atualmente, estão instalados no piso térreo do palácio uma delegação do Turismo de Portugal e o Museu do Desporto, e no piso nobre, aberto a visitas, ocorrem pequenas exposições e outros eventos culturais.

Desde 1971 o Palácio Foz está classificado como Imóvel de Interesse Público (PORTUGAL, 1971), e incluído na Zona de Proteção Especial (ZEP) do conjunto denominado "Ascensor da Glória e meio urbano que o envolve", que foi classificado como monumento nacional ( $\mathrm{MN}$ ) ao abrigo do Decreto $n^{\circ}$ 5/2002 (PORTUGAL, 2002). Esta classificação e inclusão na ZEP explicita várias restrições construtivas, das quais se pode destacar a interdição de transformar a construção ao nível estrutural, permitindo-se, porém, alterações à organização funcional. Ressalva-se que quaisquer modificações,

[...] devem assegurar a manutenção das características essenciais do meio urbano do conjunto classificado ao nível das fachadas e da cobertura preservando a imagem matricial da frente edificada (PORTUGAL, 2018, p. 21733, 21734).

\footnotetext{
2. Revolta militar que pôs fim à $1^{\text {a }}$ República e que esteve na origem do Estado Novo.

3. O palácio foi rentabilizado, até esta data, através do fracionamento e arrendamento dos seus espaços. A título de exemplo, funcionaram a pastelaria Foz no rés do chão do palácio, o restaurante Abadia na cave, e o Club Foz no piso nobre.
} 
Este trabalho incide na análise dos projetos de arquitetura e nas alterações construtivas, realizadas pelo Marquês da Foz, no período compreendido entre 1887 e 1904. Apesar do elevado peso da componente construtiva, as obras efetuadas naquele período no edifício, e particularmente as da sua envolvente, encontram-se escassamente documentadas, ao contrário das perspetivas históricas e artísticas, que estão relativamente bem estudadas (ATAÍDE, 2010; FRANÇA, 1999; MATOS, 1999; SILVA, 1999; VALE, 1999).

A caracterização arquitetónica e construtiva de um edifício é importante, no sentido em que pode auxiliar algumas tomadas de decisão nas diversas vertentes de intervenção, designadamente no património edificado com valor histórico, cultural e social (BERKOWSKI, KOSIORKAZBERUK, 2016; BERTOLIN, LOLI, 2018). Nesta perspetiva, crê-se que o estudo da evolução construtiva do edifício em análise possa contribuir para a sua melhor compreensão, e, em simultâneo, agregar informação para futuras ações de intervenção. Deste modo, pretende-se analisar do ponto de vista arquitetónico e construtivo as sucessivas alterações introduzidas nos elementos do envelope do edifício (paredes e cobertura) durante aquele período, contextualizando-as no âmbito cronológico e com a prática construtiva vigente. Tais alterações são também avaliadas através do impacto das transformações urbanísticas, na zona circundante ao palácio, durante o mesmo intervalo de tempo.

Para este estudo foram analisados os projetos registados na Câmara Municipal de Lisboa (CML) entre 1887 e 1904, e que estão atualmente depositados no Arquivo Municipal de Lisboa (AML), bem como documentos cartográficos coetâneos. Os referidos projetos correspondem a pedidos formulados pelo então proprietário Marquês da Foz, e consistem, essencialmente, em alterações, ampliações e renovações do edifício.

As reconstituições que fundamentam as descrições das componentes arquitetónica e construtiva do edifício apoiam-se, essencialmente, em registos escritos e imagens coevas, na constituição de edifícios de tipologia similar construídos após o terramoto de 1755 (edifícios pombalinos), bem como nos elementos que constituem a envolvente atualmente existente. 


\section{A CONSTRUÇÃO E RECONSTRUÇÃO DO PALÁCIO E O CONTEXTO URBANO DA CIDADE DE LISBOA NA ÁREA CIRCUNDANTE}

Após o terramoto de 1755, que arruinou grande parte do centro da cidade de Lisboa, foi prontamente desencadeado um plano de recuperação, proposto pelo general e engenheiro-mor do reino Manuel da Maya (1677-1768) e concretizado pelos arquitetos/engenheiros militares Eugénio dos Santos (1711-1760) e Carlos Mardel (1696-1763) (AYRES, 1910). Este plano foi encomendado pelo então ministro do rei D. José I, Sebastião José de Carvalho e Mello4.

O plano de reedificação da cidade de Lisboa incluiu não só a reorganização urbanística da cidade destruída, mas também a adoção de técnicas construtivas inovadoras que materializassem edifícios mais seguros perante outras situações de catástrofe sísmica e de incêndio urbano.

Os edifícios de habitação construídos em Lisboa após o sismo ficaram conhecidos por edifícios pombalinos. Estes edifícios integraram maioritariamente prédios de rendimento, mas também, segundo França (2004) algumas escassas casas nobres, entre as quais o Palácio dos Marqueses de Castelo Melhor.

A segurança dos edifícios a (re)edificar, após o terramoto de 1755, foi uma das premissas da construção pombalina. A generalidade das construções pombalinas era constituída por paredes exteriores de alvenaria de pedra que, acima do rés do chão, agregavam uma estrutura tridimensional interna de madeira, a gaiola pombalina, cuja constituição está descrita em Pinho (2000), Ramos e Lourenço (2002), Appleton (2003), Paula e Cóias (2006), Lourenço, Vasconcelos e Poletti (2014). Este sistema, concebido para resistir à ação sísmica, incluía "vários elementos que interligam paredes interiores, paredes exteriores, vigamentos de pavimentos e asnas de cobertura formando um sistema quase perfeito de solidarização dos diferentes elementos estruturais" (PINHO, 2000, p. 159).

Os tabiques, que também integravam o sistema de gaiola, consistiam numa estrutura ligeira de madeira rebocada que era pregada ao sobrado e ao teto, e que apenas tinha função de compartimentação para as divisões

\footnotetext{
4. Posteriormente titulado Marquês de Pombal, que tomou conta da pasta do reino português em maio de 1756. Foi Conde de Oeiras em 1759, e Marquês de Pombal em 1770.
} 
de menores dimensões (PINHO, 2000; RAMOS, LOURENÇO, 2002). Um trabalho sobre algumas obras empreendidas no edifício Foz referencia a existência de tabiques, a par de outras soluções construtivas mais recentes (CERDEIRA; PINTO; CORTESÃO, 1999).

$\mathrm{Na}$ verdade as paredes das fachadas dos edifícios pombalinos eram realizadas com uma estrutura de madeira denominada frontal que apenas possuía elementos ortogonais entre si. Este conjunto era encaixado inferior e superiormente em vigas paralelas às fachadas denominadas frechais. Era nos frechais que as vigas dos pavimentos se apoiavam. Os elementos diagonais só existiam nas paredes internas perpendiculares às fachadas.

Na construção de edifícios de maior valor, como é o caso do Palácio dos Marqueses de Castelo Melhor, era frequente os pavimentos incluírem, nas suas estruturas principais, arcos e abóbadas de alvenaria, uma solução mais duradoura e segura ${ }^{5}$, mas também mais onerosa, comparativamente aos sistemas construtivos da generalidade dos edifícios. Segundo Appleton (2003), as construções mais importantes erigidas a partir do século XVIII integraram madeira de pitespaine $e^{6}$ nas estruturas dos pavimentos, e, em casos mais raros, madeiras oriundas do Brasil, da Índia ou de África. Relativamente às madeiras usadas na construção do palácio dos Marqueses de Castelo Melhor, ter-se-ão usado espécies nativas oriundas do Brasil (PALÁCIO..., 1863; ALMEIDA, 1925)7.

As coberturas inclinadas, com revestimento de materiais cerâmicos, e as coberturas planas, para conformar terraços, foram as soluções construtivas mais adotadas para os edifícios daquela época construtiva. Nos edifícios de planta retangular, as coberturas inclinadas, com estruturas de madeira, podiam ter duas, três ou quatro vertentes. As coberturas planas baseavam-se em estruturas de arcos e abóbadas que eram preenchidas com materiais de enchimento até ao nível da camada de revestimento aparente,

\footnotetext{
5. Neste contexto, refere-se o alvará de 15 de junho de 1759, que no parágrafo 8 estabelece a proibição de edificar cavalariças, cocheiras e palheiros à face de ruas principais, e os "palheiros [devem ser] cobertos de abobedas, para que no caso, em que nelles haja alguns incendios fiquem sempre preservados os edifícios principaes", (Álvará de 15 de Junho de 1759, p.664).

6. Da espécie Pinus palustris (APPLETON, 2003).

7. "Grande parte das madeiras mandou do Brasil um dos últimos vice-reis d'aquelle estado, Luiz de Vasconcellos e Sousa [...]” (PALÁCIO..., 1863, p. 255). Refira-se que D. Luís de Vasconcelos e Sousa (1742-1809), $12^{\circ}$ Vice-Rei do Brasil entre 1778 e 1790 , era filho do $1^{\circ}$ Marquês de Castelo Melhor.
} 
num processo construtivo idêntico ao referido para os pavimentos suportados por sistemas de arcos e abóbadas (APPLETON, 2003).

O Palácio dos Marqueses de Castelo Melhor foi construído na área central da cidade de Lisboa junto ao Passeio Público (Figura 1), um espaço municipal de lazer, projetado em 1764 pelo arquiteto da cidade Reynaldo Manuel (1731-1791), constituído por um jardim murado que se estendia até a Praça da Alegria, e ao qual se acedia através do Rossio. Este novo espaço público, embora relativamente reservado na sua frequência, criou uma frente urbana desafogada, apresentando no seu esquema original:

[...] uma alameda de $300 \times 90 \mathrm{~m}$ constituída por uma rua central; em ambas as faixas laterais desta artéria foram plantadas cinco filas de árvores dispostas regular e simetricamente de modo a formarem ruas secundárias (CUNFF, 2003, p. 180).

FIGURA 1

Excerto da Carta topográfica de Lisboa levantada em 1807, da autoria de Duarte Fava, com a localização do novo palácio dos marqueses de Castelo Melhor assinalada através da linha de cor azul. Fonte: Biblioteca Nacional de Portugal, cota cc-1067-r. Disponível em: http://purl. pt/21796. Acesso em: 10 jul. 2019.

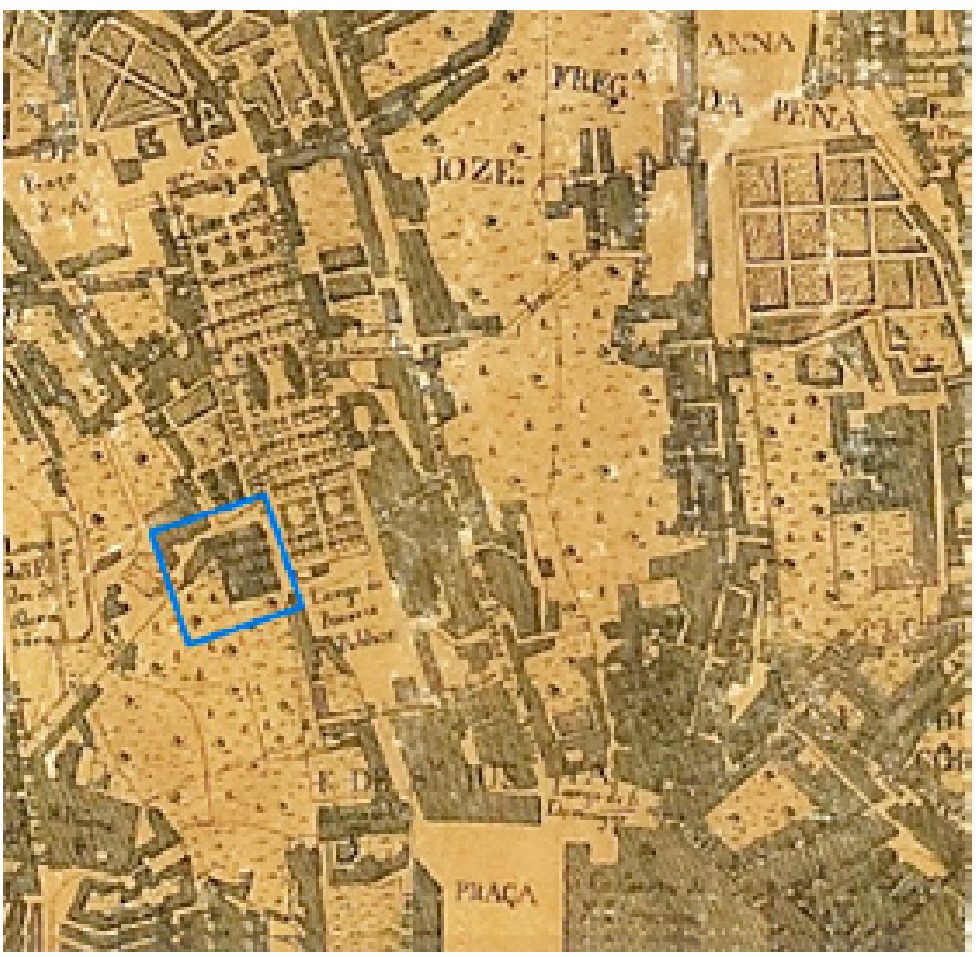


As remodelações do Passeio Público das décadas de 1830 e 1840 resultaram no seu prolongamento/ampliação ocupando parte do largo que precedia a entrada do jardim (MESQUITA, 2008). Outras alterações importantes foram as demolições das construções fronteiras ao limite sul do jardim do Palácio Foz, ainda assinaladas na planta de Duarte Fava (Figura 1), que já não são observáveis no levantamento de Perry Vidal (Figura 2), e que assim libertaram a frente nascente da propriedade dos marqueses de Castelo Melhor.

Não havendo certeza sobre a data da construção do palácio, poder-se-á apontar como período provável o que medeia entre 1785 e 1805. A construção do edifício, pelos marqueses de Castelo Melhor, só ficaria, contudo, concluída em 1858 com a capela privada, como será adiante referido.

O projeto do palácio tem sido atribuído ao arquiteto italiano Francesco Saverio Fabri (1761-1817), persistindo, no entanto, alguma controvérsia sobre a titularidade da sua autoria (ATAÍDE, 2010; CARVALHO, 1979; LEAL, 1996). De acordo com os desenhos de Fabri, a construção teria "uma sobreloja, um andar nobre e um andar de sacadas com um zimbório ao centro e um pequeno torreão em cada extremidade" (PALÁCIO..., 1863, p. 255). No entanto, este plano original teria sido alterado "porque ficaria muito elevado para a estreitesa da rua, com o avançamento que teve o Passeio Público" (PALÁCIO..., 1863, p. 255).

FIGURA 2

Excerto da planta da cidade de Lisboa contendo todos os melhoramentos posteriores a $1843, \mathrm{da}$ autoria de Frederico Perry Vidal, e sobre a qual se identificam através da linha de cor azul, o palácio dos marqueses de Castelo Melhor o limite nascente. Fonte: Biblioteca Nacional de Portugal, cota cc-1071-r. Disponível em http://purl.pt/4006. Acesso em: 10 jul 2019

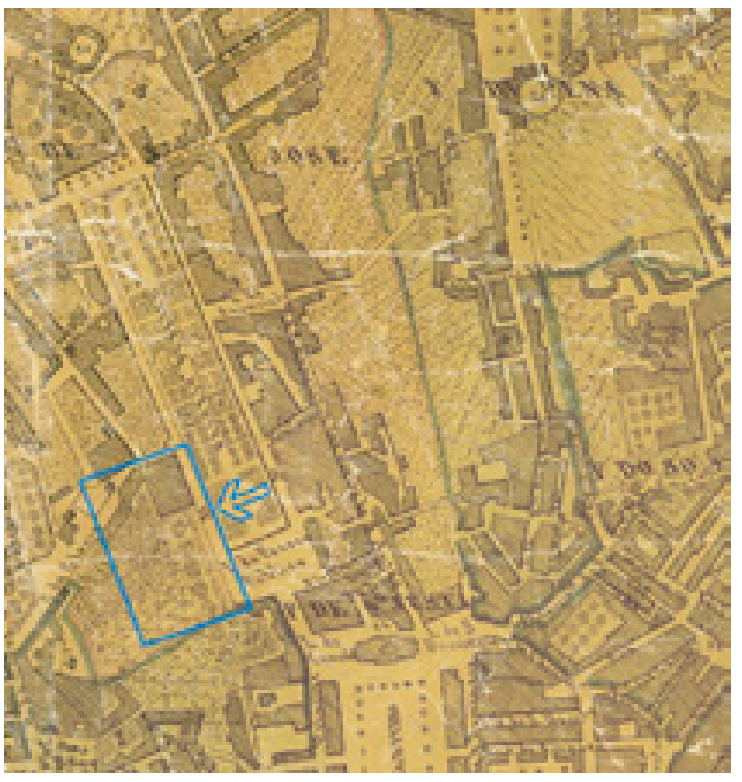




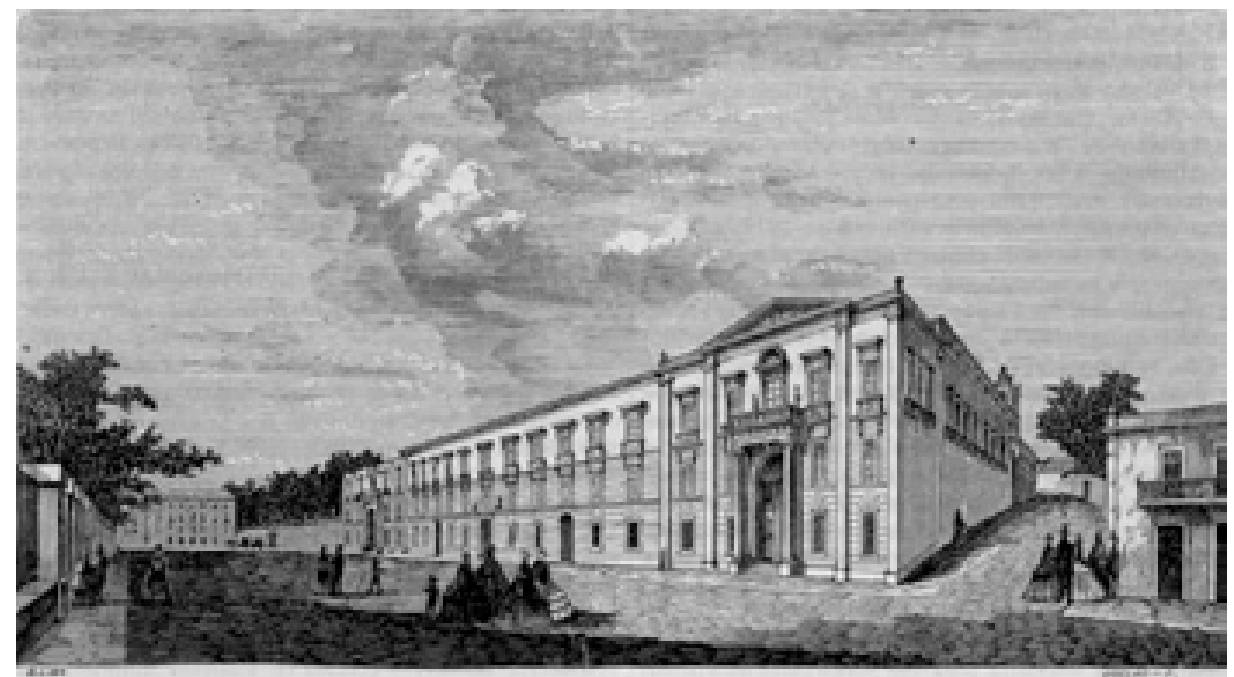

Na gravura da Figura 3, datada de 1863, a construção apresenta um piso térreo, uma sobreloja e um andar nobre. O edifício central é limitado por dois corpos laterais simétricos, os torreões norte e sul. $\mathrm{O}$ torreão norte viria, em meados do século XVIII, a alojar uma faustosa capela ${ }^{8}$, em honra de Nossa Senhora da Pureza do Amor de Deus, com revestimentos de mármore e colunas monolíticas de cantaria, tornando-a "o mais rico sanctuário particular que tem Lisboa" (PALÁCIO..., 1863, p. 255).

Em 1849, o $4^{\circ}$ Marquês de Castelo Melhor (1816-1858) apresentou nos serviços camarários o desenho que configura as instalações das cavalariças9. Entre 1854 e 1856, procedeu-se à construção e ampliação da capela, que foi concluída em $1858^{10}$.

8. A sagração da capela privada do Palácio de Castelo Melhor aconteceu a 27 de junho de 1858 (Palácio..., 1863).

9. O projeto encontra-se no Arquivo Municipal de Lisboa, AML/AH, cota 115, com o título "Prospecto das cavalariças que o marquês de Castelo Melhor pretende reedificar no seu palácio, sito na rua da Glória".

10. O desenho que corresponde à alteração e ampliação da capela é da autoria de Giuseppe Cinatti (1808-1879). Os projetos encontram-se no Arquivo Municipal de Lisboa: AML/AH, cota 8383, e AML/AH, cota 8250 . 
Em requerimentos dirigidos à CML, e separados por dois anos ${ }^{11}$, foi solicitada autorização para construir, sobre o muro de suporte dos jardins, com frente para o Largo do Passeio Público (atual Praça dos Restauradores) dois pavilhões, destinados a alocar pequenas lojas (SERRANO; MOREIRA, 2017). Como consequência da edificação da ferrovia em 1887, grande parte dos jardins do palácio foram alienados para possibilitar a construção do ramal e do túnel da futura estação do Rossio (A ESTAÇÃO..., 1960).

Em $1889^{12}$, o palácio foi vendido ao Marquês da Foz ${ }^{13}$ (ATAÍDE, 2010; VALE, 1999), que nele terá habitado entre 1887 e 1902. As imagens da Figura 4 ilustram a fachada principal do Palácio Foz, vista da Avenida da Liberdade/ Praça dos Restauradores, em 1891 (Figura 4a) e na atualidade (Figura 4b).

Quando o Marquês da Foz tomou posse do edifício, contratou José António Gaspar (1842-1909), arquiteto e autor dos desenhos do interior do edifício, Leandro Braga (1839-1897), escultor e entalhador, e Simões de Almeida (1844-1926), escultor e autor das estátuas que rematam superiormente os frontões, dos torreões norte e sul (Figura 4).

\footnotetext{
11. Em 1881, o tutor das herdeiras do Marquês de Castelo Melhor, Campos de Andrade, submeteu um requerimento à CML (no AML, este requerimento está identificado por Obra 30040, Proc. 26/1881), no qual manifestava o desejo de construir uma edificação de piso térreo com seis vãos geminados de porta, junto ao limite do passeio. Num processo posterior (no AML, este requerimento está identificado por Obra 30040, Proc. 33/1883), datado de 2 de Março de 1883, o mesmo requerente solicita autorização para edificar "lojas no terreno que possui na Rua Occidental do passeio entre a entrada para os recreios e o palácio Castelo Melhor".

12. Subsistem, porém, algumas dúvidas relativamente à data da venda do Palácio ao marquês da Foz, já que, segundo o artigo publicado na Gazeta dos Caminhos de Ferro (A ESTAÇÃO..., 1960, p.187), em 1886, o Marquês da Foz, como representante do Conselho de Administração da Companhia Real dos Caminhos-de-Ferro, inicia negociações com o tutor das herdeiras do Palácio, Campos de Andrade, para a sua aquisição.

13. O Marquês da Foz, Tristão Guedes de Queiroz Castelo Branco (1849-1917), obteve o título nobiliárquico em 1901 e era um conhecido capitalista, ligado à finança e à indústria, tendo sido o fundador e acionista maioritário da Companhia Real dos Caminhos-de-Ferro, que dirigiu entre 1884 e 1891. Foi diretor do Banco de Portugal, entre 1888 e 1891, e também manteve atividade política, como deputado pelo Partido Progressista (SANTOS, 2014).
} 
FIGURA 4

Palácio Foz: a) Fotografia da fachada principal do edifício,

datada de 1891.

Fonte: M. Caetano

Portugal (1891); b)

Fachada principal

do edifício, na atu-

alidade. Fotografia:

Autoras.
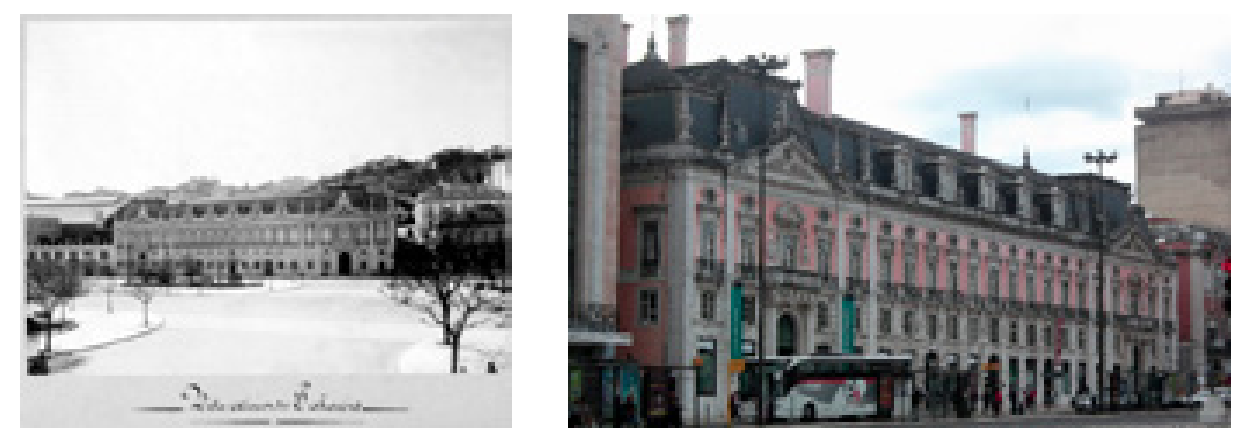

De acordo com José Fialho de Almeida (1925), as obras empreendidas no edifício, pelo Marquês da Foz, foram de grande dimensão, já que da construção original apenas se aproveitaram as paredes da fachada, e no interior a capela.

Este período correspondeu também a transformações profundas na área circundante ao palácio, que iriam reconfigurar a cidade. A 24 de agosto de 1879, iniciavam-se as obras para a abertura da Avenida da Liberdade, demolindo-se para o efeito o Passeio Público (FRANÇA, 1990). A Avenida da Liberdade, inaugurada após sete anos de trabalhos, abriu um novo espaço urbano, o desejado boulevard, que termina numa rotunda distributiva com $200 \mathrm{~m}$ de diâmetro, denominada Rotunda do Marquês de Pombal, e da qual irradiam as principais artérias de articulação do centro com o termo da cidade.

A avenida, construída sob o signo das aparências e das tecnologias modernas, a par dos entretenimentos de lazer, do passeio e do olhar, rapidamente se constituiu como lugar privilegiado da sociabilidade lisboeta:

Mas Lisboa, a foliona, quer vêr, das janellas de casa, passar os trens para o Campo Grande. Lisboa quer viver na Avenida, no perímetro da illuminação electrica, com americano á porta e os theatros á mão (DIAS, 1907, p. 279).

A criação de bairros residenciais adjacentes à avenida foi também contemplada neste plano coordenado pela repartição técnica da CML. A urbanização da área oriental adjacente à Avenida da Liberdade desenvolveu-se a partir de 1880, 
FIGURA 5

Planta esquemática de reconstituição dos possíveis limites de área ocupada pelo palácio, jardins e pavilhão sul, entre 1878 e 1904, baseada no levantamento topográfico da cidade de Lisboa (realizado entre 1877 1879) de Francisco e César Goullard, e na planta topográfica de Lisboa (elaborada entre 1904 e 1911) de Júlio Silva Pinto (as datas das reconstituições correspondem às indicadas nas respectivas folhas). Desenho: Autoras.
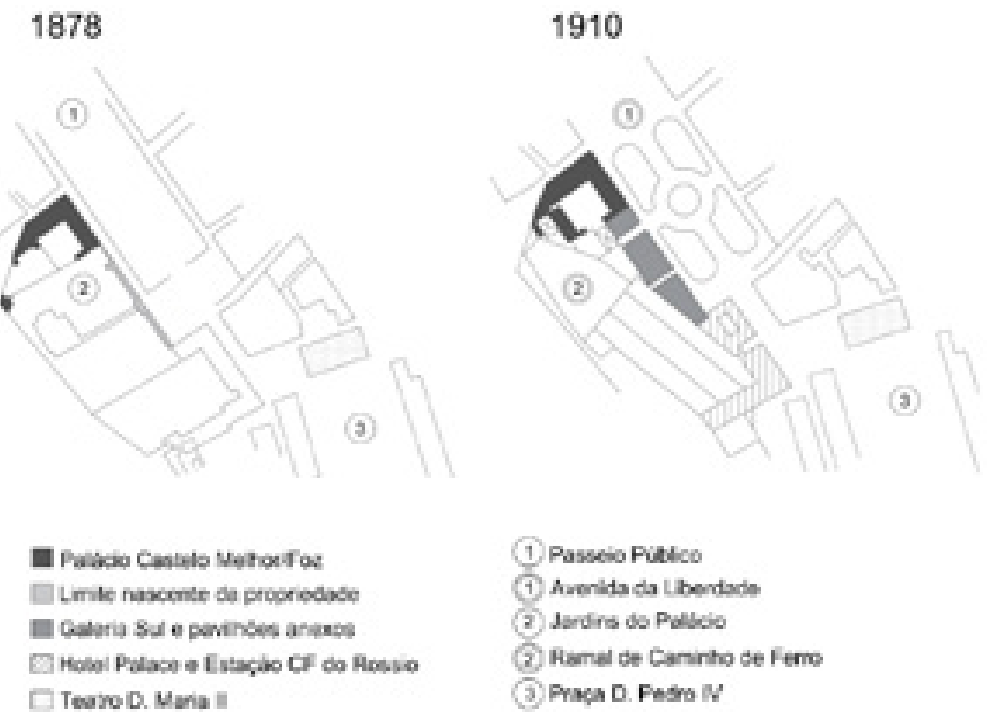

e foi promovida pelo Sindicato dos Terrenos de Santa Marta, representado por Henry Burnay (1838-1909) ${ }^{14}$. O projeto desta sociedade imobiliária consistia no "delineamento da rede viária da zona a urbanizar e no acordo para que a CML assegurasse a construção destas ruas, cedendo o Sindicato o terreno necessário" (SILVA, 1996, p. 618). A ocidente, o acordo de cedência de terrenos, entre a CML e Adriano Barata Salgueiro (1814-1895) ${ }^{15}$, permitiu o loteamento e urbanização dessa área destinada a uma burguesia abastada.

$\mathrm{Na}$ Figura 5 representa-se esquematicamente a planta de reconstituição dos possíveis limites da área ocupada pelo palácio e pelos seus anexos, entre 1877 e 1911. Esta representação foi baseada no levantamento topográfico da cidade de Lisboa (realizado entre 1877 e 1879), da autoria de Francisco e César Goullard, e na planta topográfica de Lisboa (elaborada entre 1904 e 1911) de Júlio Silva Pinto. De acordo com estes registos, a propriedade incluía, naquele período, além do edifício principal, parte do jardim exterior ${ }^{16}$ e duas construções independentes adossadas ao limite nascente que confrontava com o Largo do Passeio Público/Praça dos Restauradores (Figura 5, à direita).

14. Henry Burnay, Conde de Burnay, foi um conhecido e influente capitalista. Estabeleceu-se em Lisboa em 1875 com a firma Henry Burnay \& $C^{a}$.

15. Este advogado cedeu e vendeu à CML alguns terrenos para a prossecução do plano da Avenida da Liberdade e zonas adjacentes.

16. A partir de 1887, uma parcela significativa do jardim foi expropriado para dar lugar ao túnel e ramal da estação ferroviária do Rossio. 
Na imagem da Figura 4 à esquerda, é visível o designado pavilhão sul, contíguo ao edifício principal do palácio, construção de planta retangular e cobertura plana que, em diversos documentos, também surge referenciada como galeria ou anexo sul' ${ }^{17}$.

As reconstituições dos elementos do envelope do edifício anteriormente descritas com base nas fontes e na bibliografia consultadas, e empreendidas pelos marqueses de Castelo Melhor, e pelo Marquês da Foz, são sintetizadas no Quadro 1.

QUADRO 1

Reconstituição dos principais elementos do envelope do edifício, entre finais séc. XVIII e 1891 (as datas indicadas entre parêntesis curvos correspondem ao período/ano de construção)

\begin{tabular}{cl}
\hline $\begin{array}{c}\text { PALÁCIO CASTELO MELHOR } \\
\text { (construção original: 1785-1805) }\end{array}$ & \multicolumn{1}{c}{$\begin{array}{c}\text { PALÁCIO FOZ } \\
\text { (1889-1891) }\end{array}$} \\
\hline Paredes de cantaria (até o nível superior da sobreloja) \\
e de alvenaria de pedra revestida com reboco de argamassa (construção original). \\
\hline Piso térreo com 21 vãos de portas e janelas de peito (construção original). \\
$\begin{array}{c}\text { Cobertura inclinada com revestimento de } \\
\text { telha cerâmica, em continuidade sobre o } \\
\text { corpo central e os torreões norte e sul. }\end{array}$ & $\begin{array}{l}\text { Cobertura em mansarda sobre o corpo principal } \\
\text { do edifício, que inclui cinco janelas de sacada } \\
\text { intercaladas por quatro óculos ovais, sobre os } \\
\text { torreões norte e sul, com dois óculos ovais em cada } \\
\text { torreão. Os vãos introduzidos na cobertura em } \\
\text { mansarda correspondem a aberturas sobre a Praça } \\
\text { dos Restauradores (1887-1889). }\end{array}$ \\
\hline
\end{tabular}

Sobreloja com 19 vãos de janelas de peito (construção original).

"Andar nobre" com 21 vãos de sacadas alinhadas com os vãos dos pisos inferiores (construção original).

Torreão norte rematado, ao nível da cobertura, por frontão triangular (construção original) Capela de Nossa Senhora da Pureza integrada no torreão norte (1858).

Acréscimo de escultura na zona superior do frontão triangular do torreão norte, da autoria de Simões de Almeida (1889-1891).

Torreão sul rematado, ao nível da cobertura, por frontão triangular (construção original)

Acréscimo de escultura na zona superior do frontão triangular do torreão sul, da autoria de Simões de Almeida (1889-1891).

Construção contígua ao edifício principal: pavilhão/galeria/anexo sul (1881-1888).

Acréscimo de esculturas, a rematar o terraço do pavilhão sul (1889-1891).

17. O pavilhão sul do Palácio Foz foi demolido nos anos 1930, para aí se construir o edifício Éden. 


\section{OS REQUERIMENTOS DE OBRAS DO MARQUÊS DA FOZ, ENTRE 1887 E 1904}

No período em que o Marquês da Foz e a sua família habitaram o palácio, e a par das obras referenciadas na secção anterior, constatou-se, através da pesquisa realizada, que entraram na CML diversos requerimentos, quer respeitantes a alterações, quer a propostas de reconstrução do palácio. $\mathrm{O}$ teor dos requerimentos consultados é apresentado no Quadro 2.

\begin{tabular}{|c|c|c|c|}
\hline \multirow{12}{*}{$\begin{array}{r}\text { QUADRO } 2 \\
\text { Síntese dos } \\
\text { requerimentos para } \\
\text { obras apresentados } \\
\text { pelo Marquês da } \\
\text { Foz, na CML, entre } \\
1887 \text { e } 1904 .\end{array}$} & $\begin{array}{l}\text { DATA DO } \\
\text { REQUERIMENTO }\end{array}$ & TEOR DO REQUERIMENTO & OBSERVAÇÕES \\
\hline & $22-08-1887$ & Concluir o pavilhão sul. & \\
\hline & $12-07-1888$ & Completar o palácio. & \\
\hline & $24-07-1888$ & Ampliar o pavilhão sul. & $\begin{array}{l}\text { As obras no pavilhão sul foram } \\
\text { concretizadas. }\end{array}$ \\
\hline & AQUISIÇÃO DA P & OPRIEDADE PELO MARQUÊS DA FOZ (18 & 89) \\
\hline & $25-06-1889$ & $\begin{array}{l}\text { Incluir elementos decorativos em } 11 \\
\text { vãos de janelas do piso nobre da fachada } \\
\text { principal (sobre a Avenida da Liberdade). }\end{array}$ & $\begin{array}{l}\text { A obra foi concretizada, tendo-se } \\
\text { estendido à totalidade de vãos de janela } \\
\text { da fachada principal. }\end{array}$ \\
\hline & $22-03-1890$ & - & $\begin{array}{l}\text { Requerimento em falta no processo de } \\
\text { obra, e que viria a ser substituído pelo } \\
\text { requerimento de } 24-09-1890 \text {. }\end{array}$ \\
\hline & 24-09-1890 & $\begin{array}{l}\text { Acrescentar } 4 \text { pisos e sótão no prédio } \\
\text { da Praça dos Restauradores. }\end{array}$ & $\begin{array}{l}\text { A obra foi concretizada. Atualmente, este } \\
\text { edifício não faz parte do Palácio Foz. }\end{array}$ \\
\hline & $10-09-1891$ & $\begin{array}{l}\text { Alterar a fachada posterior referente ao } \\
\text { edifício resultante da ampliação. }\end{array}$ & $\begin{array}{l}\text { Não existem dados para confirmar a } \\
\text { concretização da obra. }\end{array}$ \\
\hline & $10-03-1899$ & $\begin{array}{l}\text { Abrir vãos de porta, na fachada voltada } \\
\text { para a Calçada da Glória. }\end{array}$ & A obra foi concretizada. \\
\hline & $15-01-1902$ & $\begin{array}{l}\text { Construir "cinco grandes casas", com } \\
5 \text { pisos, no terraço anexo ao edifício } \\
\text { principal do palácio. }\end{array}$ & A obra não foi concretizada. \\
\hline & 1904 & $\begin{array}{l}\text { Abrir } 15 \text { vãos de janela na fachada } \\
\text { voltada para a Calçada da Glória. }\end{array}$ & A obra foi concretizada. \\
\hline
\end{tabular}


O primeiro requerimento do Marquês da Foz, com registo na CML, data de 22 de agosto de 1887 (ARQUIVO MUNICIPAL DE LISBOA, 1887, obra 5236, proc. 4770/87), e refere-se ao pedido de conclusão do pavilhão sul, depreendendo-se que, naquela data, o edifício se mantinha inacabado. No requerimento escrito (e cujo anexo desenhado está em falta no AML) lê-se, ainda, que o Marquês da Foz pretendia remodelar o palácio ao nível decorativo, mas que estava impossibilitado de tal por ser arrendatário do imóvel, como se transcreve:

O Marquês da Foz desejando terminar a construção do pavilhão sul da sua propriedade sita na praça dos restauradores, $\mathrm{n}^{\circ} 28$ a 31 [...] conforme projecto junto, contando seguidamente reconstruir toda a propriedade subordinando-a à decoração da fachada que apresentar, o que não pode fazer desde já, por se achar esta parte cativa de um arrendamento de longo prazo (ARQUIVO MUNICIPAL DE LISBOA, 1887, obra 5236, proc. $4770 / 87$, f. 1$)$.

No ano seguinte, a 12 de julho (ARQUIVO MUNICIPAL DE LISBOA, 1888a, obra 5236, proc. 4795/88), o Marquês da Foz entrega novo requerimento para completar o palácio.

A 24 de julho de 1888, assinala-se outro pedido (ARQUIVO MUNICIPAL DE LISBOA, 1888b, obra 5236, proc. 4798/88), para dar continuidade às obras no pavilhão sul, em substituição do projeto aprovado pela CML em 1887 (ARQUIVO MUNICIPAL DE LISBOA, 1887, obra 5236, proc. 4770/87). Este requerimento refere-se à ampliação do pavilhão sul, através da adição de um piso superior. O desenho que acompanha o pedido é escasso em informação, representando a planta do piso nobre do palácio e do pavilhão sul, à escala 1:10o (Figura 6). No mesmo desenho é incluído um corte transversal (A-B) sobre a planta do pavilhão sul que se apresenta na Figura 7. No desenho da planta dos dois edifícios (Figura 6), as paredes da fachada principal do pavilhão sul são representadas de forma análoga às paredes exteriores do palácio, o que leva a crer que a constituição da parede da fachada principal do pavilhão seria semelhante à das paredes exteriores do palácio. No desenho do corte transversal do pavilhão (Figura 7), a parede posterior constitui-se por um muro de suporte de terras, fazendo supor que os jardins do palácio se desenvolveriam ao nível da cota da cobertura plana do pavilhão. 
O pavilhão sul, com dois pisos, teria uma área de implantação de aproximadamente $500 \mathrm{~m}^{2}$ (39 $\mathrm{m}$ comprimento e $13 \mathrm{~m}$ de largura), pé direito $4,40 \mathrm{~m}$ no primeiro piso, e 3,20 m no segundo, de acordo com o mesmo documento.

FIGURA 6

Extrato do desenho que representa a planta do piso nobre do Palácio Foz, e do piso ao mesmo nível do pavilhão sul; a linha de cor verde representa o contorno das paredes exteriores do palácio; a linha contínua de cor azul representa

o contorno das paredes exteriores do pavilhão. Fonte: Arquivo Municipal de Lisboa (1888b, obra 5236, proc 4798/88, f. 3).

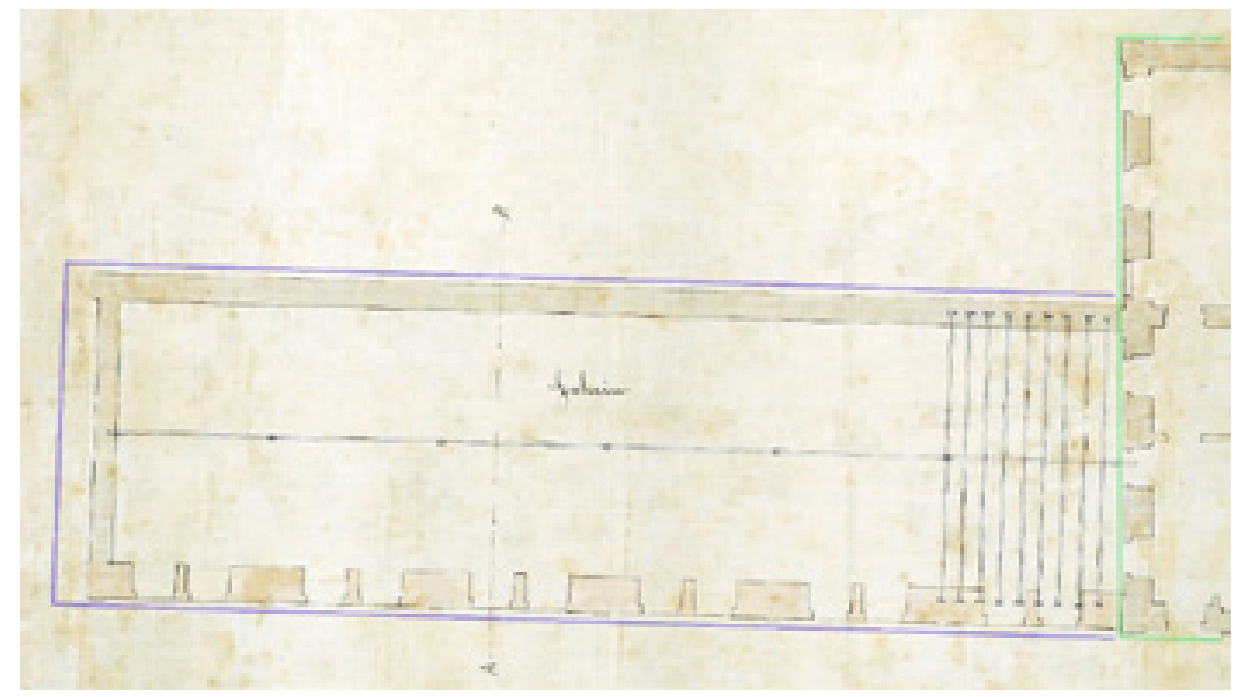

FIGURA 7

Extrato do desenho anexo a que representa o corte transversal do pavilhão sul. Fonte: Arquivo Municipal de Lisboa (1888b, obra 5236, proc. $4798 / 88$, f. 3 )

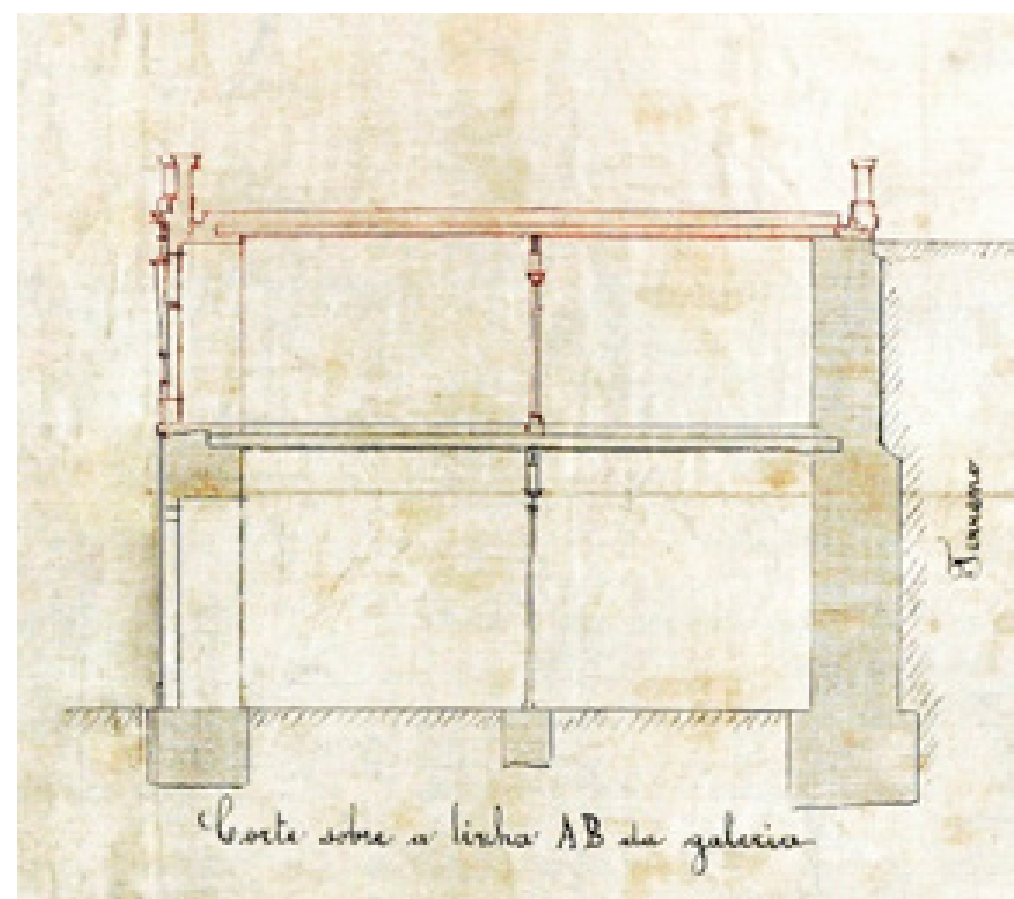




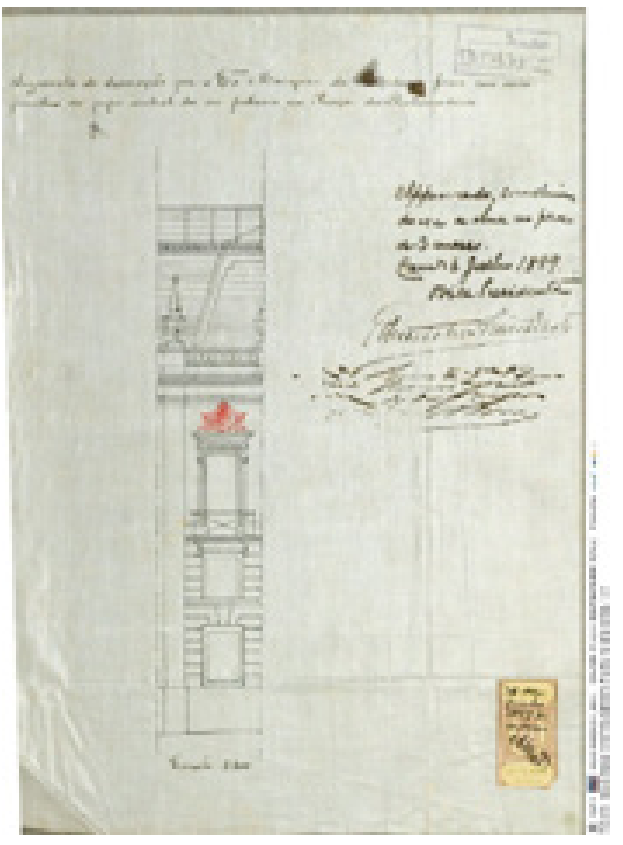

Em 1889, a 25 de junho, através de requerimento (ARQUIVO MUNICIPAL DE LISBOA, 1889, obra 5236, proc. 5329/89), o Marquês da Foz solicita autorização para acrescentar ornamentos nas 11 janelas da fachada principal do corpo central do palácio ${ }^{18}$. No desenho, à escala 1:100, anexo a este requerimento (Figura 8), a fachada é rematada por friso, cornija e platibanda em balaustrada, e limitada lateralmente por pilastra encimada por um pináculo. Apesar do pedido explicitar 11 janelas do corpo central, a decoração acabou por se estender a todas as janelas do piso nobre, tal como hoje as podemos apreciar (Figura 4 b). Atendendo ao pormenor da cobertura incluída no mesmo pedido (Figura 8), admite-se que a alteração da cobertura original para mansarda tenha sido realizada entre 1887 e 1889, uma vez que nos processos consultados, no AML, não se encontraram registos relacionados com a substituição da cobertura inclinada original (como sugere a gravura de 1863 apresentada na Figura 3), pela cobertura em mansarda. De acordo com Almeida (1925), a cobertura em mansarda foi realizada a mando do Marquês da Foz, como parte da intervenção atribuída ao arquiteto José António Gaspar, responsável pela direção da construção, e ao escultor Leandro Braga, a quem se imputam as decorações dos frontões.

'18. Esta intenção foi anteriormente expressa (ARQUIVO MUNICIPAL DE LISBOA, 1887, obra 5236, proc. 4770/87), mas a sua concretização colidia com o facto do marquês não ser, nessa data, proprietário do palácio. 
Em 1890, o Marquês da Foz propõe-se aumentar o número de pisos do pavilhão situado no extremo sul da Praça dos Restauradores ${ }^{19}$. No AML existem dois processos (ARQUIVO MUNICIPAL DE LISBOA, 189oa, obra 5236 , proc. $1899 / 90,189 \mathrm{ob}$, proc. $8665 / 90$ ) correspondentes a este projeto. $\mathrm{O}$ primeiro requerimento (ARQUIVO MUNICIPAL DE LISBOA, 189oa, obra 5236, proc. 1899/9o) encontrava-se em falta no AML, quando foi realizada a consulta para o presente artigo. No requerimento, datado de 24 de setembro de 1890 (ARQUIVO MUNICIPAL DE LISBOA, 189ob, obra 5236, proc. 8665/90), refere-se a intenção de acrescentar quatro pisos e um sótão ao pavilhão. Este projeto consistia no aproveitamento parcial do piso térreo do edifício, e de parte do jardim, até o muro da estação ferroviária do Rossio (que se pode ver na representação à direita da Figura 5), para a construção de um prédio de quatro pisos com o aproveitamento da zona sob a cobertura. Tratava-se de um edifício com um acesso central em escadas de dois lanços, e com um único fogo por piso. A fachada principal, voltada para a Praça dos Restauradores, apresentava uma disposição tripartida com um corpo central limitado por pilastras e duas alas simétricas. Face à extensão em comprimento do edifício, foi necessário intercalar três saguões para ventilar e iluminar as divisões meãs. $\mathrm{O}$ requerimento foi analisado e aprovado pelo diretor da repartição técnica da CML, engenheiro Frederico Ressano Garcia (1847-1911), que, em nota informativa (ARQUIVO MUNICIPAL DE LISBOA, 189o, obra 5236, inf. 14169/CML), advertiu o requerente para o facto de a altura do edifício proposto ser superior à regulamentar ${ }^{20}$.

Entre 1887 e 1891, o Marquês da Foz empreendeu grandes reformas na sua propriedade, tanto nos pavilhões adjacentes como no edifício principal (PALÁCIO..., 1863; ALMEIDA, 1925), registadas através de várias fotografias (PORTUGAL, 1891) que ilustram alguns aposentos, e o faustoso recheio do edifício, após as obras de renovação.

Os pedidos para alterações no palácio e nas suas dependências foram novamente solicitados pelo Marquês da Foz: um, em 1891, referente

19. Junto ao futuro hotel Avenida Palace que se situava entre a estação do Rossio e a Praça dos Restauradores, tendo ligação directa para a estação. Foi projetado pelo arquiteto José Luiz Monteiro (1848-1942), por encomenda da Companhia Real dos Caminhos-de-Ferro Portugueses, e inaugurado em 1892. 20. A Lei de 2 de julho de 1867 (PORTUGAL, 1867) instituiu como altura máxima dos alçados dos edifícios $20 \mathrm{~m}$, para ruas cuja largura excedesse $7 \mathrm{~m}$. 
à modificação da fachada posterior do edifício resultante da ampliação requerida em 1890 (ARQUIVO MUNICIPAL DE LISBOA, 1891, obra 5236, proc. 8194/91); e outro em 1899, relativo ao edifício principal do palácio, nomeadamente à abertura de um vão na fachada lateral norte, confinante com a Calçada da Glória ${ }^{21}$.

A crise financeira de 1891 precipitou a falência do Marquês da Foz (SANTOS, 2014), que abandonou a residência da avenida em 1899, sucedendo-se a venda em leilão de todo o seu recheio, em 1901 (ATAÍDE, 2010). No mesmo ano já estavam concluídas a Avenida Fontes Pereira de Melo, que ligava, através da Rotunda do Marquês de Pombal, no topo da Avenida da Liberdade, a zona de Picoas; e parte da Avenida Ressano Garcia (atual Avenida da República), que ampliava a cidade até o Campo Grande. Foi neste contexto que a Avenida da Liberdade ganhou um novo fôlego, tendo-se estabelecido finalmente como eixo de articulação entre o centro pombalino e as novas avenidas da cidade, resultantes do plano de expansão urbana que se iniciara nas últimas décadas do século XIX (SILVA, 1989).

Em 1902, o Marquês da Foz solicitou, através do requerimento de 15 de janeiro (ARQUIVO MUNICIPAL DE LISBOA, 1902a, obra 5236, proc. 250/1902), autorização para a construção de um edifício de habitação no local ocupado pelo palácio e galeria sul. Este ambicioso projeto, que substituía as construções existentes entre a Calçada da Glória e a Praça dos Restauradores, consistia num bloco de cinco prédios contíguos. Era constituído por edifícios de seis pisos com um acesso principal centralizado, e ainda um segundo acesso sobre o alçado tardoz. Cada piso comportaria dois fogos, aproximadamente simétricos. As habitações seriam constituídas por oito a onze compartimentos e uma casa de banho. De acordo com o projeto, na fachada voltada para a Avenida da Liberdade, abrir-se-iam quatro vãos de janela, e para o jardim do palácio, no alçado posterior, três vãos de janela.

21. Trata-se do requerimento datado de 10 de Março de 1899. O Processo não se pode identificar porque a folha está danificada nessa zona. No requerimento lê-se "O Marquez da Foz desejando abrir uma porta na parede da sua propriedade sita na calçada da Glória entre os números 7 e 9 medindo esta porta 2.10×1.80 m e não podendo fazer sem a licença da Exa. Câmara por isso [...] Declaro para todos os efeitos assumir a responsabilidade desta obra nos termos do decreto de 6 de Junho de 1895 . Lisboa 10 de Março 1899 Frederico Augusto Ribeiro" (AML, obra 5236, processo não identificável, f. 1). 
A iluminação e a ventilação das divisões meãs seriam garantidas por dois saguões, permanecendo, no entanto, duas divisões interiores ${ }^{22}$.

O parecer sobre este projeto, datado de 14 de fevereiro de 1902 (ARQUIVO MUNICIPAL DE LISBOA, 1902b, obra 5236, inf. 2147/CML) e assinado pelo engenheiro Frederico Ressano Garcia, condicionou a sua aprovação à eliminação de um dos pisos nobres, de forma a não se exceder a altura total legalmente estabelecida, 20 m (PORTUGAL, 1867). A mesma informação salientou, ainda, que nenhum dos pisos tivesse menos de $3 \mathrm{~m}$ de altura livre. A construção e a demolição do edifício existente foram taxadas com o valor de $430 \$ 00$ (quatrocentos e trinta escudos), não tendo sido assinalado qualquer outro impedimento. O projeto não foi, contudo, transposto em obra.

Ainda que possam ter existido razões de índole diversa a fundamentar as últimas propostas de intervenção no complexo $\mathrm{Foz}^{23}$, julga-se, no âmbito deste trabalho, que para tais decisões também terá contribuído a valorização urbanística decorrente das transformações que ocorreram naquela zona de Lisboa. A cidade adquiriu um valor paisagístico de modernidade que tomou corpo neste cenário, e onde a Avenida da Liberdade,

[...] assume um papel de destaque pois inaugura em Lisboa os novos valores do urbanismo moderno e constitui-se como palco de experiências arquitectónicas pioneiras. Estas oscilam entre os modestos prédios de rendimento destinados à classe média, as moradias que ostentam linguagens exuberantes de teor ecléctico e os palacetes da alta burguesia que legitimam o estatuto e a dignidade social dos seus proprietários (MESQUITA, 2008, p. 207).

A última alteração de vulto manifestada pelo Marquês da Foz data de 1904, quando solicitou autorização de novo projeto para outras alterações no edifício do palácio: a abertura de quinze vãos na fachada lateral confinante com a Calçada da Glória (Figura 9), e a demolição de paredes interiores que permitissem a construção de uma escada, em substituição de uma (escada)

22. Apenas a partir de 1903, através do Regulamento de Salubridade das Edificações Urbanas, regulado pelo Decreto de 14 de Fevereiro de 1903, publicado no Diário do Governo de 17 de fevereiro de 1903, p. 66-70, existiu obrigatoriedade na iluminação e ventilação de todos os compartimentos, como se depreende da redação dos artigos $11^{\circ}, 13^{\circ}, 18^{\circ}, 19^{\circ}$ e $20^{\circ}$ do regulamento.

23. Tais como a saída do Marquês da Foz dos cargos públicos que ocupava e o retiro para a sua propriedade rural, em Torres Novas (SANTOS, 2014). 


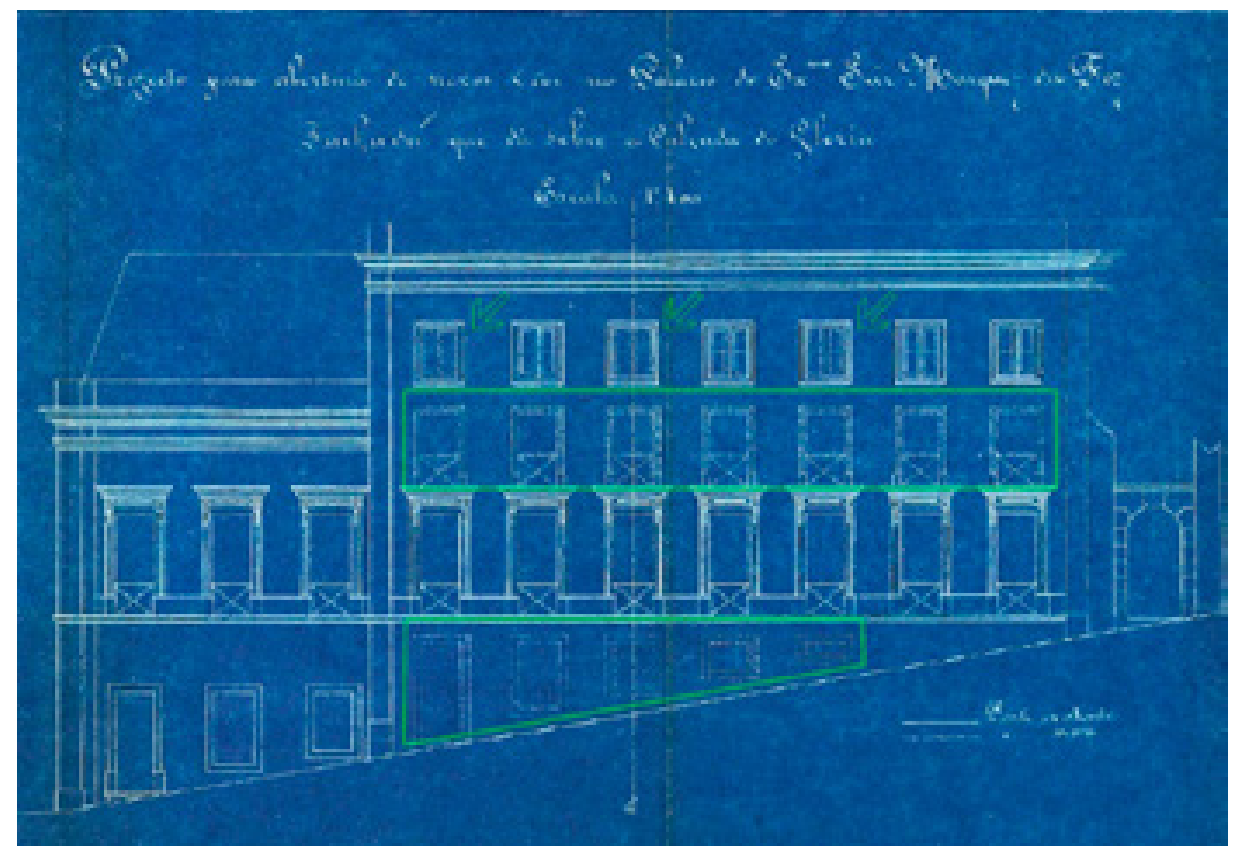

existente no lugar da antiga capela, por aquela se encontrar degradada (ARQUIVO MUNICIPAL DE LISBOA, 1904, obra 5236, proc. 822/1904). A responsabilidade da obra foi assumida pelo arquiteto Raúl Lino (1879-1974), tendo a mesma sido concretizada, ainda que apenas as obras referentes à abertura dos vãos sobre a Calçada da Glória possam ser comprovadas.

Através da informação contida neste último pedido, infere-se, relativamente à capela do palácio, que entre o ano de publicação do Álbum do Palácio dos Marquezes da Foz $z^{24}$, em 1891 (PORTUGAL, 1891), e o deste requerimento, 1904, a capela terá desaparecido, pelo menos na função de recinto religioso.

\section{CONSIDERAÇÕES FINAIS}

O Palácio de Castelo Melhor foi construído pelo $1^{\circ}$ Marquês de Castelo Melhor, após o terramoto de Lisboa, ocorrido em 1755, para residência da família. O edifício foi, no final da década de 1880, adquirido pelo Marquês da Foz, que nele habitou e realizou consideráveis obras de reconstrução. Após esta aquisição, o edifício passou a designar-se Palácio Foz, tal como é atualmente conhecido. 
Neste artigo coligiram-se as alterações arquitetónicas e construtivas projetadas no Palácio Foz, através da reconstituição baseada na análise documental dos projetos de obras de alteração submetidos à CML pelo Marquês da Foz entre 1887 e 1904. Nesta abordagem enquadraram-se as perspetivas arquitetónicas e construtivas, com as transformações urbanísticas da envolvente.

Os pedidos de autorização das obras submetidos à CML, durante o intervalo de tempo analisado, incidiram sobre o edifício principal, o palácio, com a fachada sobre a atual Praça dos Restauradores e Avenida da Liberdade, e sobre as construções contíguas a este edifício, designadamente o pavilhão sul. Esse pavilhão constituiu uma construção, de planta retangular com dois pisos e cobertura plana, adjacente ao torreão sul do palácio, no alinhamento da sua fachada principal. Uma parte desta construção foi demolida na década de 1930, e outra, localizada no limite sul da praça dos restauradores, foi, de acordo com o projeto de 1902, ampliada e transformada num edifício de habitação plurifamiliar.

Do processo de análise realizado, no período compreendido entre 1887 e 1904, é possível afirmar que as obras empreendidas pelo Marquês da Foz implicaram algumas alterações no edifício principal, designadamente ao nível da configuração da cobertura, na abertura de vãos para receber portas e janelas e na capela. A tais alterações podem ser imputados períodos cronológicos, com base nos respectivos requerimentos:

a) 1887-1889: Substituição da estrutura da cobertura inclinada original pela estrutura da cobertura em mansarda;

b) 1889: Decoração de todos os vãos de janela da fachada principal do palácio (sobre a Avenida da Liberdade);

c) 1899: Abertura de vão de porta no piso térreo da fachada lateral norte do palácio (voltado para a Calçada da Glória, na zona mais próxima da fachada principal);

d) 1904: Abertura de 15 vãos de janelas na fachada lateral norte do palácio (sobre a Calçada da Glória): cinco no piso térreo, e os restantes nos pisos superiores.

Os documentos analisados permitem também afirmar que a galeria sul, construção anexa ao edifício principal e projetada entre 1881 e 1883, teria 
sido concluída entre 1887 e 1888, e que a capela, inserida no torreão norte do palácio, foi desmantelada no período compreendido entre 1891 e 1904.

$\mathrm{Na}$ pesquisa documental realizada não se encontraram registos sobre os materiais usados ou sobre as tecnologias construtivas, ou sobre o seu modo de aplicação. Assim, será importante proceder ao levantamento, análise e caracterização dos materiais existentes na constituição do edifício principal do palácio para, assim, complementar a sua caracterização construtiva.

É possível que alguns dos últimos projetos para o complexo Foz, designadamente os referentes à construção de prédios de rendimento, tenham resultado da tentativa de fazer face às dificuldades económicas que advieram da insolvência do Marquês, através da rentabilização dos seus espaços. Contudo, é igualmente importante referir as transformações urbanas que ocorreram na área circundante ao palácio, designadamente a construção da Avenida da Liberdade e das vias envolventes. Estas alterações urbanas permitiram ampliar e diversificar a oferta de habitação multifamiliar, e também marcar um espaço de transição entre a Baixa da cidade e os espaços de expansão oitocentistas.

As propostas do Marquês da Foz podem, então, ser entendidas como argumento de transformação de uma área urbana, onde a tipologia palaciana se desencontra do seu espaço matricial. Na Avenida da Liberdade, bem como no seu prolongamento a Nordeste e nas zonas adjacentes, irão prevalecer outras tipologias de habitação, sob a forma de prédio de rendimento, ou moradia, por vezes eclécticos palacetes urbanos, já sem a dimensão do Palácio Foz. Este edifício, com a imponente fachada sobre a Praça dos Restauradores e Avenida da Liberdade, cuja propriedade se foi fragmentando desde o final do século XIX, cedeu lugar à ferrovia urbana, a partir da estação do Rossio, e aos espaços de lazer, que marcaram a vida mundana da nova avenida da cidade.

\section{AGRADECIMENTOS}

As autoras agradecem a colaboração do dr. Ricardo Máximo, do Palácio Foz e do AML e Fundação Calouste Gulbenkian pela cedência das imagens. 


\section{REFERÊNCIAS}

A ESTAÇÃO do Rossio e a linha Urbana de Lisboa. Gazeta dos Caminhos de Ferro, Lisboa, n. 1742, p. 183-19o, 196o. Disponível em: http://hemerotecadigital.cm lisboa.pt/OBRAS/

GazetaCF/1960/N1742/N1742_master/GazetaCFN1742.pdf. Acesso em: 15 jan. 2018.

ALMEIDA, José Fialho de. Vida errante (Livro póstumo). Lisboa: Livraria Clássica Editora, 1925.

APPLETON, João. Reabilitação de edifícios antigos: patologias e tecnologias de intervenção. Lisboa: Edições Orion, 2003.

ARQUIVO MUNICIPAL DE LISBOA. Obra 5236. Processo n. 4770/87. Lisboa: AML, 1887.

ARQUIVO MUNICIPAL DE LISBOA. Obra 5236. Processo n. 4795/88. Lisboa: AML, 1888a.

ARQUIVO MUNICIPAL DE LISBOA. Obra 5236. Processo n. 4798/88b. Lisboa: AML, 1888b.

ARQUIVO MUNICIPAL DE LISBOA. Obra 5236. Processo n. 5329/89. Lisboa: AML, 1889.

ARQUIVO MUNICIPAL DE LISBOA. Obra 5236. Processo n. 1899/9o. Lisboa: AML, 1890 .

ARQUIVO MUNICIPAL DE LISBOA. Obra 5236. Processo n. 8665/9o. Lisboa: AML, 189 ob.

ARQUIVO MUNICIPAL DE LISBOA. Obra 5236. Processo n. 8194/91. Lisboa: AML, 1891.

ARQUIVO MUNICIPAL DE LISBOA. Obra 5236. Processo n. 250/1902. Lisboa: AML, 1902a.

ARQUIVO MUNICIPAL DE LISBOA. Obra 5236. Informação 2147/CML. Lisboa: AML, 19o2b.

ARQUIVO MUNICIPAL DE LISBOA. Obra 5236. Processo n. 822/1904. Lisboa: AML, 1904.

ARQUIVO MUNICIPAL DE LISBOA. Obra 5236. Informação 14169/CML. Lisboa: AML, 189 o.

ATAÍDE, Carlos. Palácio Foz = Foz Palace. Lisboa: Gabinete para os Meios de Comunicação Social, 2010.

AYRES, Cristóvão. Manuel da Maya e os engenheiros militares portugueses no terramoto de 1755 . Lisboa: Imprensa Nacional, 1910. Disponível em: http://purl.pt/848/6/sa-4322-4-a_PDF/sa-43224-a_PDF_24-C-Ro15o/sa-4322-4-a_oooo_capa-6o_t24-C-Ro15o.pdf. Acesso em: 18 jan. 2018.

BERKOWSKI, Piotr; KOSIOR-KAZBERUK, Marta. Construction history as a part of assessment heritage buildings. Procedia Engineering, Amsterdam, n. 161, p. 85-90, 2016.

BERTOLIN, Chiara; LOLI, Arian. Sustainable interventions in historic buildings: a development decision making tool. Journal of Cultural Heritage, Amsterdam, n. 34, p. 291-302, 2018.

CARVALHO, Armindo Ayres de. Os três arquitectos da Ajuda do "Rocaille" ao Neoclássico: Manuel Caetano de Sousa (1742-1802), José da Costa e Silva (1747-1819), Francisco Xavier Fabri (1761-1817). Lisboa: Academia Nacional de Belas-Artes, Direcção-Geral do Património Cultural, 1979.

CERDEIRA, António; PINTO, José; CORTESÃO, Luísa. Intervenções recentes da DirecçãoGeral dos Edifícios e Monumentos Nacionais. Revista Monumentos, Lisboa, n. 11, p. 49-57, 1999. 
CUNFF, Françoise. Do passeio público ao parque da liberdade. Revista Camões, Lisboa, n. 15-16, p. 179-186, 2003. Disponível em: http://cvc.instituto-camoes.pt/conhecer/biblioteca-digital-camoes/revistas-e-periodicos/revista-camoes/revista-no15-16-marques-de-pombal.html. Acesso em: 12 fev. 2019.

DIAS, Carlos Malheiro. Cartas de Lisboa ( $3^{\circ}$ série - 1905-06). Lisboa: Livraria Clássica Editora, 1907.

FERNANDES, José Manuel. Luís Benavente e o Palácio Foz. Revista Monumentos, Lisboa, n. 11, p. 26-28, 1999.

FRANÇA, José-Augusto. Lisboa: urbanismo e arquitectura. 2. ed. Lisboa: Instituto de Cultura e Língua Portuguesa, 1990. (Biblioteca Breve, v. 53).

FRANÇA, José-Augusto. O Palácio de Castelo Melhor ao Passeio Público. Revista Monumentos, Lisboa, n. 11, p. 9-13, 1999.

FRANÇA, José-Augusto. História da arte em Portugal: o Pombalismo e o Romantismo. Lisboa: Editorial Presença, 2004.

LEAL, Joana. Giuseppe Cinatti (1808-1879): percurso e obra. 1996. Dissertação (Mestrado em História de Arte Contemporânea) - Faculdade de Ciências Sociais e Humanas, Universidade Nova de Lisboa, Lisboa, 1996.

LOURENÇO, Paulo; VASCONCELOS, Graça; POLETTI, Elisa. Edifícios pombalinos: comportamento e reforço. In: SEMINÁRIO INTERVIR EM CONSTRUÇÕES EXISTENTES DE MADEIRA, 2014, Guimarães. Livro de Atas. Guimarães: Universidade do Minho, 2014. p. 1-10. Disponível em: http://www.hms.civil.uminho.pt/events/intervir_madeira/fulltext_Intervir_ madeira.pdf. Acesso em: 4 fev. 2019.

MATOS, José Sarmento. O Palácio Castelo Melhor. Revista Monumentos, Lisboa, n. 11, p. 15-19, 1999.

MESQUITA, Marieta Dá. Lisboa no século XIX: intervenções urbanas. Revista Pós, São Paulo, v. 15, n. 24, p. 196-212, 2008.

SERRANO, Inês Domingues; MOREIRA, Anabela Mendes. Adaptações dos espaços da Casa Nobre: o Palácio Foz, em Lisboa. In: CONGRESSO INTERNACIONAL DA CASA NOBRE: UM PATRIMÓNIO PARA O FUTURO, 5, 2017, Arcos de Valdevez. Livro de Atas. Arcos de Valdevez: Câmara Municipal de Arcos de Valdevez. No prelo

PALÁCIO dos Marquezes de Castello Melhor, ao Passeio Público. Archivo Pittoresco, Lisboa, v. 6, n. 32, p. 253-255, 1863. Disponível em: http://hemerotecadigital.cm-lisboa.pt/Periodicos/ ArquivoP/1863/TomoVI/N32/N32_master/ArquivoPitoresco1863N32.PDF. Acesso em: 12 jan. 2018.

PAULA, Raquel; CÓIAS, Victor. Rehabilitation of Lisbon's old “seismic resistant” timber framed buildings using innovative techniques. In: INTERNATIONAL WORKSHOP ON EARTHQUAKE ENGINEERING ON TIMBER STRUCTURES, 2006, Coimbra. Atas [...]. Coimbra: Universidade de Coimbra, 2006. p. 33-46. Disponível em: http://www.enmadera.info/ cost/e29/wsh/3\%2ocoimbra/o61108\%20cost\%2oseismic\%2ocoimbra.pdf. Acesso em: 4 fev. 2019.

PINHO, Fernando. Paredes de edifícios antigos em Portugal. Lisboa: Laboratório Nacional de Engenharia Civil, 2000.

PORTUGAL, M. Caetano. Álbum do Palácio dos Marquezes da Foz em Lisboa, anno de 1891. [S. l.; s. n.], 1891: Disponível em: http://baimages.gulbenkian.pt/images/winlibimg. aspx?skey $=\& d o c=225870 \& i m g=70861$. Acesso em: 11 jun. 2018. 
PORTUGAL. Legislação Régia. Decreto de 31 de dezembro de 1864. Regulando a construcção, conservação e policia das estradas de $10^{\mathrm{a}}, 2 .^{\mathrm{a}} \mathrm{e} 3{ }^{\mathrm{a}}$ ordens, e das ruas que fazem parte d'ellas no interior das cidades, villas e mais povoações do reino. Diário de Lisboa, LIsboa, n. 10, p. 19411949, 13 jan. 1865. Disponível em: http://legislacaoregia.parlamento.pt/V/1/39/96/p1077. Acesso em: 13 jun. 2018.

PORTUGAL. Legislação Régia. Lei de 2 de julho de 1867. Alterando algumas disposições do decreto de 31 de dezembro do 1864, sobre viação publica. Diário de Lisboa, Lisboa, n. 147, p. 438, 5 jul. 1867. Disponível em: http://legislacaoregia.parlamento.pt/V/1/42/79/p456. Acesso em: 10 jun. 2018.

PORTUGAL. Ministério da Educação Nacional. Decreto 516/71, de 10 de novembro de 1971. Procede à classificação de vários imóveis como monumentos nacionais, [...] e à classificação de imóveis de interesse público [...]. Diário do Governo, Lisboa, n. 274, 22 nov. 1971. Série 1, p. 1798-1799. Disponível em: https://dre.pt/application/file/631681. Acesso em: 12 jan. 2019.

PORTUGAL. Ministério da Cultura. Decreto no 5/2002, de 19 de dezembro de 2001. Procede à classificação de 107 imóveis como monumentos nacionais e imóveis de interesse público. Diário da República, Lisboa, n. 42/2002, 19 fev. 2002. Série 1-B, p. 1364-1399. Disponível em: https://dre. pt/application/conteudo/278071. Acesso em: 12 jan. 2019.

PORTUGAL. Ministério da Cultura. Portaria nº 394/2018, de 19 de julho de 2018. Fixa a zona especial de proteção e as restrições aplicáveis ao Ascensor da Glória e meio urbano que o envolve [...]. Diário da República, Lisboa, n. 15, 9 ago. 2018. Série 2, p. 21733-21734. Disponível em: https://dre.pt/application/conteudo/115944674. Acesso em: 12 jan. 2019.

RAMOS, Luís; LOURENÇO, Paulo. Análise da vulnerabilidade sísmica de um quarteirão da Baixa Pombalina. In: CONGRESSO NACIONAL DE ENGENHARIA DE ESTRUTURAS, 2002, Lisboa. Livro de Atas. Lisboa: Laboratório Nacional de Engenharia Civil, 2002. p. 479-488. Disponível em: https://www.researchgate.net/publication/239279307_ANALISE_DA_ VULNERABILIDADE_SISMICA_DE_UM_QUARTEIRAO_DA_BAIXA_POMBALINA. Acesso em: 12 jun. 2018.

SANTOS, Luís. Tristão Guedes de Queirós Correia Castelo Branco, $1^{\circ}$. marquês da foz: um capitalista português nos finais do século XIX. Vila Nova de Gaia: Inovatec, 2014. Disponível em: http://issuu.com/foztua/docs/marquesdafoz. Acesso em: 12 fev. 2019.

SILVA, Álvaro Ferreira. A construção residencial em Lisboa: evolução e estrutura empresarial (1860-1930). Análise Social, Lisboa, v. 31, n. 136-137, p. 599-629, 1996.

SILVA, Raquel (ed.). Lisboa de Frederico Ressano Garcia 1874-1909. Lisboa: Câmara Municipal de Lisboa, 1989.

SILVA, Raquel. O Palácio Castelo Melhor: contexto e projecto inici27/o6/2019al. Revista Monumentos, Lisboa, n. 11, p. 21-25, 1999.

VALE, Teresa. Da sumptuosidade e da ostentação: os interiores do Palácio Foz nos últimos anos de Oitocentos. Revista Monumentos, Lisboa, n. 11, p. 31-35, 1999. 